faculty member takes on executive responsibility for an outside corporation, makes use of unpublished findings from university research in outside projects, or takes to another location research which would ordinarily be carried out on campus.

University administrators are pains to point out that such guidelines will be interpreted flexibly. Dr Walter Gilbert, for example, has recently been given leave of absence to work as chief executive officer of the Geneva-based Biogen, but will be able to return to his post as professor of molecular biology at a later date.

Stanford University, which has more formal guidelines than most universities because of the involvement of its faculty members in the microelectronics industry, is also tightening them up. The faculty will meet next month to decide whether to adopt a set of proposals that would require any research worker to disclose the names of companies with whom he or she consults and the nature of the consultancy agreement to the appropriate dean or head of department.

The Stanford proposals, made public in the early summer, are also designed to ensure that neither faculty members nor the departments to which they belong should make fortunes from the licensing of patents; academics will usually receive a third of any profits, but departments will have to share with the university if their income exceeds a certain proportion of their budget.

A different, although closely related, set of issues has emerged at the Massachusetts
Institute of Technology (MIT), where $\mathrm{Mr}$ Edwin (Jack) Whitehead, founder and former president of Technicon Corporation and now the largest shareholder in Revlon which recently bought Technicon from him, has offered to build and endow an independent institute for research into molecular approaches to developmental biology (Nature 1 October, p.329) at a total cost of $\$ 127$ million.

Although strongly supported by the MIT administration, the proposal has generated considerable controversy among faculty members over the implications of the possible "dual allegiance" of the 20 new professors who would be appointed to the MIT faculty but have their salaries and research expenses totally paid for by the Whitehead Institute. At a meeting on 1 October during which several criticisms of the proposed arrangements were raised, faculty members called on the MIT administration to take their concerns into account in further negotiations.

Meanwhile conflict-of-interest concerns are even reaching the top ranks of the mass media. Mr Walter Cronkite, until recently anchorman of CBS's nightly evening news, announced on Friday that he was resigning as a director of Pan American Airways since this could conflict with his work on space topics for the new CBS science program Cosmos. Earlier this year $\mathrm{Mr}$ Cronkite withdrew from taking part in CBS's coverage of the first launch of NASA's space shuttle, a project for which Pan Am has contracts. David Dickson

\title{
Solidarity for university freedom
}

The transformation of the Polish free trade union Solidarity into a multilateral social movement was completed at its first congress in September-October. The congress in Gdansk discussed a wide range of proposals and programmes and in particular called for a new approach to education, involving "social control" over the whole educational process.

The formal resolution derives from the report of a special working group which, among other things, advocated liberalization and self-government in higher education, an end to censorship and free access to the works of Polish scholars living abroad.

It also called for university and research finances to be effectively under the control of "academic and social milieux". Scientific exchanges with foreign scholars should be increased, and more funds made available for the purchase of books and learned journals from abroad. Just how this could be accomplished in Poland's present economic crisis is hard to see - although Solidarity does, of course, have its own proposals for economic recovery.

One interesting suggestion is that a new system of "social funding" of research and higher education should be developed, in parallel with the government sector. On the Polish Academy of Science which, it is suggested, is too isolated from the rest of the academic community, the group advocated the removal of all "barriers" with the academic community, with the understanding that scholars working for the academy should be able to give lectures and seminars for students.

The group also asks that the status and authority of scholars should be restored by solving the "personnel problem" in various universities, a reference to those academics who owe their positions to patronage rather than academic prowess. Academic degrees should be awarded by competent scholars who enjoy the full trust of their fellows - without, it is implied, the possibility of government or party influence.

The most startling proposal raised by the working group, however, is that Solidarity should found its own private university in Szczecin, taking as a precedent the Catholic University of Lublin. On this point, however, the working group failed to reach a consensus, and the proposal was deferred for further study.

\section{University organization London gives up}

The committee set up a year ago to devise a new structure for the University of London's non-medical schools is being scrapped. Last week, Professor Randolph Quirk, the university's new vicechancellor, explained in a letter to Sir Peter Swinnerton-Dyer, the committee's chairman, that the worsening of the university's finances over the past 18 months made the committee's original brief virtually impossible. Since the committee produced its first discussion document last January, the university's financial prospects have changed from a 15-20 per cent cut in real income by the end of the decade to a 20 per cent cut over the next three years.

The response to the committee's interim recommendations last May was mixed. In particular, suggestions that Chelsea College should close and Bedford and Westfield colleges should merge met with protests. Academics may be relieved at the committee's demise, but their respite will be brief. Professor Quirk hopes that the subject review committees, which he set up last month to advise on resource allocation by January, will establish criteria on which the university can determine its future for itself. The review committees will assess the quality of teaching and research in biological, physical and engineering sciences, languages and social studies in all colleges of the university.

The Swinnerton-Dyer committee, however, has been asked to report by December on the university's central activities, including research and teaching institutes, the central library, unions and sports facilities and central administration. The idea is that the committee's work will form part of the information used to help allocate future resources.

Meanwhile, the university is still struggling with an even older problem that of rationalizing its medical schools. The recommendation in early 1980 of a working party chaired by Lord Flowers that London's 34 medical institutes be merged into six large schools was protested at more strongly than the Swinnerton-Dyer proposals.

Lord Flowers' grand plan has since been superseded by piecemeal decisions on the fate of individual schools. Hence St George's Hospital Medical School is to increase its intake of preclinical students from 200 to 250 by 1985 , the preclinical courses at Westminster and Charing Cross Hospital medical schools are to merge, the Royal Free Hospital Medical School is to remain much as it is and Guy's and St Thomas's Hospital Medical Schools are to merge.

Later this month, university officials will meet to discuss whether to merge the three large medical schools in north central London - St Mary's, the Middlesex and 